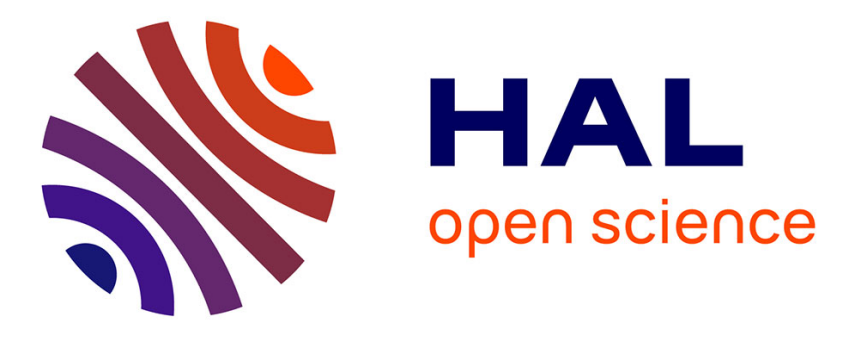

\title{
Single Crystal and Sintered Alumina Corrosion in Liquid Sodium
}

\author{
Jean-Louis Courouau, Marlu-Cesar C Steil, Jacques Fouletier, Fabien \\ Rouillard, Véronique Lorentz, Patrick Bonnaillie, Anthony Muccioli, Jonathan \\ Unger, Sandy Tricoit, Michel Tabarant
}

\section{To cite this version:}

Jean-Louis Courouau, Marlu-Cesar C Steil, Jacques Fouletier, Fabien Rouillard, Véronique Lorentz, et al.. Single Crystal and Sintered Alumina Corrosion in Liquid Sodium. Oxidation of Metals, 2017, 87 (5-6), pp.789-800. 10.1007/s11085-017-9743-3 . cea-02388860v2

\section{HAL Id: cea-02388860 \\ https://hal-cea.archives-ouvertes.fr/cea-02388860v2}

Submitted on 17 Jun 2020

HAL is a multi-disciplinary open access archive for the deposit and dissemination of scientific research documents, whether they are published or not. The documents may come from teaching and research institutions in France or abroad, or from public or private research centers.
L'archive ouverte pluridisciplinaire HAL, est destinée au dépôt et à la diffusion de documents scientifiques de niveau recherche, publiés ou non, émanant des établissements d'enseignement et de recherche français ou étrangers, des laboratoires publics ou privés. 


\title{
Single crystal and sintered alumina corrosion in liquid sodium
}

\author{
Jean-Louis COUROUAU ${ }^{\mathrm{a}}$, Marlu-César STEIL ${ }^{\mathrm{b}, \mathrm{c}}$, Jacques FOULETIER ${ }^{\mathrm{b}, \mathrm{c}}$, Fabien \\ ROUILLARD ${ }^{a}$, Véronique LORENTZa ${ }^{\mathrm{a}}$ Patrick BONNAILLIE ${ }^{\mathrm{d}}$, Anthony MUCCIOLI ${ }^{\mathrm{a}}$, \\ Jonathan UNGER ${ }^{\mathrm{a}}$, Sandy TRICOIT', Michel TABARANT ${ }^{\mathrm{e}}$ \\ ${ }^{a}$ Den-Service de la Corrosion et du Comportement des Matériaux dans leur Environnement (SCCME), CEA, \\ Université Paris-Saclay, F-91191, Gif-sur-Yvette, France \\ bUniv. Grenoble Alpes, LEPMI, F-38000 Grenoble, France \\ 'CNRS, LEPMI, F-38000 Grenoble, France \\ ${ }^{d}$ Den-Service de Recherches de Métallurgie Physique (SRMP), CEA, Université Paris-Saclay, F-91191, Gif-sur-Yvette, \\ France \\ ${ }^{e}$ Den-Service d'Etudes Analytiques et de Réactivité des Surfaces (SEARS), CEA, Université Paris-Saclay, F-91191, Gif- \\ sur-Yvette, France
}

jean-louis.courouau@cea.f; cesar.steil@lepmi.grenoble-inp.fr; jacques.fouletier@lepmi.grenoble-inp.fr ; fabien.rouillard@cea.fr; veronique.lorentz@cea.fr; patrick.bonnaillie@cea.fr; anthony.muccioli@edf.fr; jonathan.unger@cea.fr; sandy.tricoit1@areva.com; michel.tabarant@cea.fr

\begin{abstract}
Corrosion tests are achieved in static conditions at 450 and $550{ }^{\circ} \mathrm{C}$ for various oxygen contents and durations with single crystal and sintered alumina regarded as model materials for ceramics. Extremely pure and dense sintered alumina presents no intergranular corrosion and identical behavior as single crystal. Corrosion appears to proceed by reaction of $\mathrm{Al}_{2} \mathrm{O}_{3}$ with dissolved oxygen $\left(\mathrm{Na}_{2} \mathrm{O}\right)$ to form sodium aluminate $\left(\mathrm{NaAlO}_{2}\right)$. Then, sodium aluminate is dissolved in liquid sodium upon a mechanism still to be elucidated. The corrosion morphology is equivalent to dissolution. From weight loss measurement, linear kinetics is found with a constant dissolution rate of $(61 \pm 2) \cdot 10^{-4} \mathrm{mg} \cdot \mathrm{dm}^{-2} \cdot \mathrm{h}^{-1}$ at $550^{\circ} \mathrm{C}$ and low oxygen content ( $\left.<1 \mathrm{ppm}\right)$. No significant corrosion rate could be measured at $450^{\circ} \mathrm{C}$ and low oxygen content. An order reaction kinetics with respect to dissolved oxygen content of $0.6 \pm 0.2$ is found.
\end{abstract}

Keywords: alumina, sodium, corrosion, kinetics

\section{INTRODUCTION}

The use of liquid sodium at high temperature as a coolant in systems such as Sodium Fast Reactor (SFR) [1], concentrated solar power, heat pipes, etc., requires that liquid metal and materials interactions must be well understood in order to be able to predict the corrosion and to guarantee the service life-time of the component. Ceramic oxides are envisaged for monitoring the dissolved oxygen content of the liquid metal (oxygen sensor: $\mathrm{ThO}_{2}-, \mathrm{HfO}_{2-}$ and $\mathrm{ZrO}_{2}$-based electrolytes). Alumina and zirconia are envisaged for protecting the core catcher structure and ease the spreading of the molten core material (corium) in severe accident situations with core material relocation [2-5]. Both applications require that the ceramics material be compatible with the liquid metal in conditions and durations corresponding to the application: 250 to $400^{\circ} \mathrm{C}$ for low duration (1000 h at least) for sensors, and $400{ }^{\circ} \mathrm{C}$ for 60 years for the core catcher. For this latter, even though direct contact of the ceramic materials with sodium will probably be prevented by the use of steel cladding or steel deposits, the ceramic 
Courouau, J., Steil, M., Fouletier, J. et al. Single Crystal and Sintered Alumina Corrosion in Liquid Sodium. Oxid Met 87, 789-800 (2017). https://doi.org/10.1007/s11085-017-9743-3

Post print version - The final publication is available at link.springer.com

oxides ability to withstand the liquid sodium corrosion must be demonstrated for long-term reactor operation and from a safety point of view. In both cases, the dissolved oxygen concentrations as well as the sodium velocity are expected to be low $(<10 \mathrm{ppm}, \sim \mathrm{cm} / \mathrm{s})$ in the normal operating conditions [2]. Over the extended service lifetime of the reactor, some incidental conditions should also be taken into account for the long-term corrosion prediction, such as some events at higher than expected oxygen levels ( $15 \mathrm{ppm}$ for $100 \mathrm{~h}$ [2]). Indeed, the core catcher cannot be repaired nor replaced, so that its long-term degradation might shorten the reactor's lifetime. The lacks of understanding and of specific data for these ceramics justify why these materials were not used in SFR built reactors. In previous works, we have demonstrated that the microstructure of the ceramic was a key factor for corrosion resistance in liquid sodium $[4,5]$. The object of the present paper is to study the alumina behavior in liquid sodium. In this context, the single crystal and high purity sintered alumina could be regarded as models for the studies of homogenous corrosion by liquid sodium.

\section{CERAMIC MATERIALS AND LIQUID SODIUM ISSUE}

The main corrosion mechanism of ceramic by liquid sodium are as follows: thermomechanical effects such as those related to temperature change inducing a potential sensitivity to thermal shocks, localized corrosion at grain boundaries that involves both intergranular corrosion (IGC) and liquid metal penetration, homogeneous corrosion at interfaces in contact with liquid sodium as well as with trace impurities such as dissolved oxygen, and reduction of the ceramic oxide by liquid sodium. The IGC is particularly damaging since once initiated over a depth of several grains, rows of grains could become detached, leading to large weight loss or even to the complete disintegration of the specimen over a relatively short time. According to Kano and Mayer [6-7], trace impurities in ceramic such as silica $\left(\mathrm{SiO}_{2}\right)$ play a major role in its occurrence: silica is said to segregate at grain boundaries and to preferentially react with liquid metal or with dissolved oxygen, according to the following thermodynamically possible reactions (free enthalpies from [8]):

$$
\begin{array}{lll}
\mathrm{SiO}_{2}+\mathrm{Na}_{2} \mathrm{O}=\mathrm{Na}_{2} \mathrm{SiO}_{3} & -230 \mathrm{~kJ} / \mathrm{mol} \text { at } 400^{\circ} \mathrm{C}=-233484+4.631 \mathrm{~T} & -136 \mathrm{~kJ} / \mathrm{mol} \text { at } 400{ }^{\circ} \mathrm{C} \\
3 / 2 \mathrm{SiO}_{2}+2 \mathrm{Na}=\mathrm{Na}_{2} \mathrm{SiO}_{3}+1 / 2 \mathrm{Si} & \mathrm{QC}^{\circ}=-210774+111.5 \mathrm{~T} & -130
\end{array}
$$

Kinetics is fast above $300{ }^{\circ} \mathrm{C}[9]$. Sodium silicate $\left(\mathrm{Na}_{2} \mathrm{SiO}_{3}\right)$ forms probably a liquid phase at the grain boundary and is highly soluble in liquid sodium. It most probably favors liquid metal penetration and affects grain cohesion. In the tests reported by Kano [6], the alumina samples, with trace levels of impurities below $100 \mathrm{ppm}$, presented negligible intergranular corrosion after $1000 \mathrm{~h}$ in liquid sodium at $650^{\circ} \mathrm{C}$ and $1 \mathrm{ppm}$ of oxygen.

The homogeneous corrosion refers to reactions of the substrate with liquid sodium or its impurities at the interface according to reactions similar to equations (1) and (2) producing the more thermodynamically stable sodium aluminate $\left(\mathrm{NaAlO}_{2}\right)$ :

$$
\begin{array}{lll}
1 / 2 \mathrm{Al}_{2} \mathrm{O}_{3}+1 / 2 \mathrm{Na}_{2} \mathrm{O}=\mathrm{NaAlO}_{2} & -\mathrm{CG}^{\circ}=-86524-5.369 \mathrm{~T}[8] & -90 \mathrm{~kJ} / \mathrm{mol} \text { at } 400{ }^{\circ} \mathrm{C} \\
2 / 3 \mathrm{Al}_{2} \mathrm{O}_{3}+\mathrm{Na}=\mathrm{NaAlO}_{2}+1 / 3 \mathrm{Al} & \square \mathrm{C}^{\circ}=-16838+11.503 \mathrm{~T}[10] & -9 \mathrm{~kJ} / \mathrm{mol} \text { at } 400{ }^{\circ} \mathrm{C}
\end{array}
$$

The only ternary oxides taken into account here are those of the lowest stoichiometry, assumed as the most stable: $\left(\mathrm{Na}_{2} \mathrm{O}\right)_{x} \cdot\left(\mathrm{M}_{\mathrm{y}} \mathrm{O}_{z}\right), \mathrm{x}$ being the lowest value. All other compounds such as sodium silico-aluminate $\left(\mathrm{Na}_{2} \mathrm{O} \cdot \mathrm{Al}_{2} \mathrm{O}_{3} .2 \mathrm{SiO}_{2}\right)$ are neglected for the moment. The available literature data suggest that the reaction kinetics of these thermodynamically more stable oxides is low. Jung [9] observed the formation of sodium aluminate layer, with a colored (blackened) alumina zone underneath, on high density and high purity alumina specimen immersed in static condition at $900{ }^{\circ} \mathrm{C}$ in oxygen saturated sodium, conditions that are extremely severe. The thickness of the sodium aluminate layer appeared to increase with increasing test duration $(400 \mu \mathrm{m}-100 \mathrm{~h})$. For the less severe testing conditions encountered in Kano's study [6], no surface layer nor colored zone could be observed after $1000 \mathrm{~h}$ at $650^{\circ} \mathrm{C}$ and $1 \mathrm{ppm}$ oxygen, and small weight loss was systematically measured. Although oxygen plays a critical role in these corrosion mechanisms, it is not well documented in the literature, as the reactants are not identified. The surface reaction appears as similar to oxidation, followed eventually by a step of oxide reduction or oxide dissolution within the liquid metal. There is also a possibility of sodium aluminate 
Courouau, J., Steil, M., Fouletier, J. et al. Single Crystal and Sintered Alumina Corrosion in Liquid Sodium. Oxid Met 87, 789-800 (2017). https://doi.org/10.1007/s11085-017-9743-3

Post print version - The final publication is available at link.springer.com

hydrolysis in the aqueous solution used to remove sodium residue. The apparent 'dissolution' reaction is then characterized by weight loss, as measured by Kano [6] and should then present a receding interface. Jung [9] observed the formation of thick sodium aluminate layer, either because the volume of the test capsule was small so that the liquid metal got quickly saturated in dissolved sodium aluminate oxide, or because the conditions were extremely severe both in temperature and in oxygen content, or for both reasons. Lastly, sodium may reduce the oxide substrate because of its high reducing oxygen potential, leading to the formation of metal (Al) as well as to the formation of point defects, also known as colored centers or ' $\mathrm{F}$ ' centers ( $V_{\dot{O}}^{*}$ according to the Kröger \& Vink notation). This blackened surface layer presents a thickness that increases with temperature and exposure time [9], but only a small fraction of the vacancies are involved. Heat treatment of the specimen (800 ${ }^{\circ} \mathrm{C}-2 \mathrm{~h}$ ) after the sodium test corresponds to the re-oxidation: weight gain appears indeed as negligible [9]. However, if its effect on the mechanical properties is unknown, its effect on the electrical properties is an increase of the electronic conduction. All of these interactions are additionally influenced by the porosity and the microstructure of the ceramic oxide that is little documented in the literature too.

High density and high purity polycrystalline sintered 0 -alumina as well as single crystals of alumina were chosen for the studies of homogenous corrosion by liquid sodium in order to evaluate, mainly, the effect of the liquid metal on alumina substrate, independently of microstructure and grain boundaries related effects.

\section{EXPERIMENTAL PROCEDURES}

Sintered ceramic with no open porosity and high chemical purity ( $>99.7 \%$ in weight) was supplied by UMICORE (DEGUSSIT AL23 grade: $60 \mu \mathrm{g} / \mathrm{g}$ of $\mathrm{SiO}_{2}, 90 \mu \mathrm{g} / \mathrm{g}$ of CaO, $190 \mu \mathrm{g} / \mathrm{g}$ of $\mathrm{Fe}_{2} \mathrm{O}_{3}, 500 \mu \mathrm{g} / \mathrm{g}$ of $\mathrm{Na}_{2} \mathrm{O}, 1460 \mu \mathrm{g} / \mathrm{g}$ of $\mathrm{MgO}, 300 \mu \mathrm{g} / \mathrm{g}$ of $\mathrm{K}_{2} \mathrm{O}$ [7]) in the shape of tubes with $1.95 \mathrm{~mm}$ internal diameter, $3.9 \mathrm{~mm}$ external diameter, and $20 \mathrm{~mm}$ in length. The mean grain size was $10 \mu \mathrm{m}$. Single crystal of alumina was supplied by Rubis SA in the form of rod of $20 \mathrm{~mm}$ in diameter, cut with diamond disk with no further preparation other than degreasing.

TABLE 1. Test conditions in static liquid sodium.

\begin{tabular}{|c|c|c|}
\hline Temperature & [0] $\left(\mathrm{ppm}, 10^{-6}{\left.\mathrm{~g} \cdot \mathrm{g}^{-1}\right)}^{-1}\right.$ & Durations (h) \\
\hline $450^{\circ} \mathrm{C}$ & $<1 \mathrm{ppm}$ & $250-500-1000-2000-4000 \mathrm{~h}$ \\
\hline $450^{\circ} \mathrm{C}$ & $\sim 40 \mathrm{ppm}$ & $1000 \mathrm{~h}$ \\
\hline $550^{\circ} \mathrm{C}$ & < $1 \mathrm{ppm}$ & $3400 \mathrm{~h}$ \\
\hline $550^{\circ} \mathrm{C}$ & 1-5 ppm & $650-1500-3050-3950-4600 \mathrm{~h}$ \\
\hline $550^{\circ} \mathrm{C}$ & $\sim 40 \mathrm{ppm}$ & $2000 \mathrm{~h}$ \\
\hline $550^{\circ} \mathrm{C}$ & $240 \mathrm{ppm}$ & $250 \mathrm{~h}$ \\
\hline
\end{tabular}

The tests were run in the testing workbench called "CORRONa" [2,11]. The sodium was contained in a molybdenum crucible $(2.3 \mathrm{~kg})$. A furnace heated the thermal well where the crucible was set. This well is set below an argon purified glove box that simplifies all operations required for preparation of the test and handling of the liquid metal. During corrosion test, the system was perfectly tight towards both the atmosphere and the argon of the gloves box. Before testing, the $99.95 \%$ pure sodium (Métaux Spéciaux - ER grade) was melted and the free level was skimmed off in order to remove sodium oxide present in excess. A low temperature step at $105^{\circ} \mathrm{C}$ was then done for $\sim 300 \mathrm{~h}$, analog to a decantation step, followed by the skimming off any residual oxides present at the free level. Then, a last purification step was achieved at high temperature $\left(\sim 630^{\circ} \mathrm{C}\right.$ during $\left.75 \mathrm{~h}\right)$ with large surface zirconium foil $(150 \times 300 \times 0.125 \mathrm{~mm}-\mathrm{Neyco})$ to getter any residual oxygen. This foil was removed after the purification step and sometimes replaced with a new one to maintain as low as possible the oxygen concentration. Oxygen was then assessed to be lower than $1 \mathrm{ppm}$, while, without $\mathrm{Zr}$ getter during the sodium test, the oxygen was assessed to 1 to $5 \mathrm{ppm}$ (latter referred to 'low oxygen'). The qualitative appearance of the free level confirmed this assessment as perfect mirror was obtained. The amount of oxygen present in the liquid metal when no $\mathrm{Zr}$ purification was done was evaluated to $40 \mathrm{ppm}$ by characterizations of $\mathrm{Zr}$ foils. The $200 \mathrm{ppm}$ oxygen condition was obtained by adding, after the zirconium purification step, the required amount 
Courouau, J., Steil, M., Fouletier, J. et al. Single Crystal and Sintered Alumina Corrosion in Liquid Sodium. Oxid Met 87, 789-800 (2017). https://doi.org/10.1007/s11085-017-9743-3

Post print version - The final publication is available at link.springer.com

of sodium oxide to the liquid metal ( $\mathrm{Na}_{2} \mathrm{O}$ - Alfa Aesar). It must be noticed that pure new sodium is carburizing, meaning a high carbon activity $[12,13]$. The specimens were then immersed in the liquid sodium at $110^{\circ} \mathrm{C}$ and the system was tightly closed so that the liquid metal equilibrates with the argon cover gas, inducing a negligible oxygen contamination but preventing any further contamination by the argon of the gloves box. Sodium was heated to $450^{\circ} \mathrm{C}$ or $550^{\circ} \mathrm{C}$ at $0.5^{\circ} \mathrm{C} / \mathrm{min}$ and the temperature was kept constant for the duration required. When sodium reached $97 \%$ of the test temperature, the time of exposure started to be counted, assuming that any corrosion at lower temperature than the test temperature is negligible. Such low ramps were chosen to prevent any thermomechanical effects during heating or cooling. Temperature was then decreased at $0.5{ }^{\circ} \mathrm{C} / \mathrm{min}$ to remove one set of samples and possibly replace the set by a new one. Most of the time, other specimens were exposed during the same tests, mainly steels $(316 \mathrm{~L}(\mathrm{~N}), \mathrm{Fe}-9 \mathrm{Cr}-1 \mathrm{Mo}, 800$ alloys, pure $\mathrm{Ni}$, Fe, etc.) or ceramic materials (zirconia, hafnia). The surface over volume ratio averaged $0.9 \mathrm{dm}^{-1}$, mainly due to the steels specimens, neglecting the Mo crucible surface. After immersion in liquid sodium, the specimens were washed with $99.9 \%$ pure ethanol (Carlo Erba supplier) in order to remove metallic sodium residue from the sample surface and were stored in desiccators. After the first washing and weighting, a second cleaning in pure water was performed. Table 1 recalls the conditions achieved during the tests.

The specimens were then weighted to get the weight variation. Morphological characterizations were performed by means of electron microscopy: Scanning Electron Microscopy (SEM) was used to characterize surface and specimen cross-sections (device: Zeiss - Gemini ultra 55). In both cases, Energy Dispersive X-ray analyses were done (EDX, device: Bruker AXS Flash Detector 4010). Cross-sections were prepared by fracture in order to assess the fracture mode as an indication of the liquid metal penetration and reaction at grain boundaries. Such observation was made by tilting the specimen in the SEM to analyze both the fractured cross section, the interface and the surface at the same time (latter referred to 'tilted specimen').

\section{RESULTS AND DISCUSSION}

Table 2 presents a synthesis of the weight variation measured for the various specimens after the first cleaning in ethanol and the second cleaning with pure water. The weight variation equals the difference between the final and initial weights over the specimen surface, in order to measure the specific weight loss. Negative value means then a weight gain. The accuracy of the balance is $10 \mu \mathrm{g}$. The specimen reactive surface was calculated from its geometrical dimensions with a relative uncertainty of about $1 \%$. The errors propagation gives a net error of about $1 \mathrm{mg} . \mathrm{dm}^{-2}$. The macroscopic change of alumina materials through sodium exposure appeared as limited, as almost no change in color was observed. The color of all the specimens was grayish after the first ethanol cleaning, attributed to sodium residue, but returned to white after a second more efficient pure water cleaning. Single crystal surface, originally mirror-polished like, turned to a de-polished surface. 
Courouau, J., Steil, M., Fouletier, J. et al. Single Crystal and Sintered Alumina Corrosion in Liquid Sodium. Oxid Met 87, 789-800 (2017). https://doi.org/10.1007/s11085-017-9743-3

Post print version - The final publication is available at link.springer.com

TABLE 2. Alumina weight loss in relation to test conditions, in static liquid sodium.

$(*: 2$ specimens tested for the same exposure time; ': one at the beginning of the test and the latter at the end; !: weight loss after $3^{\text {rd }}$ cleaning, water + US 15 minutes).

\begin{tabular}{|c|c|c|c|c|c|c|}
\hline Materials & $\begin{array}{l}\text { Specimen } \\
\text { geometry }\end{array}$ & $\begin{array}{l}\text { Sodium } \\
\text { tempera- } \\
\text { ture }\left({ }^{\circ} \mathrm{C}\right)\end{array}$ & $\begin{array}{c}\text { Time of } \\
\text { exposur } \\
\text { e (h) }\end{array}$ & $\begin{array}{l}\text { Oxygen } \\
\text { content } \\
\text { (ppm) }\end{array}$ & $\begin{array}{l}\text { Weight loss } \\
\text { after } 1^{\text {st }} \\
\text { cleaning } \\
\left(\mathrm{mg} . \mathrm{dm}^{-2}\right) \\
\end{array}$ & $\begin{array}{c}\text { Weight loss } \\
\text { after } 2 \\
\text { cleaning } \\
\left(\mathrm{mg} . \mathrm{dm}^{-2}\right)\end{array}$ \\
\hline $\begin{array}{l}\text { Sintered } \\
\text { alumina }\end{array}$ & Tube & 550 & $\begin{array}{l}660^{* \prime} \\
1550^{* \prime} \\
3025^{*} \\
3920^{*} \\
4577^{* \prime}\end{array}$ & $1-5$ & $\begin{array}{c}4.07-7.86 \\
-12.14-3.88 \\
-45.63-34.97 \\
-195.59-28.23 \\
29.45\end{array}$ & $\begin{array}{c}3.7-8.25 \\
2.86-17.09 \\
14.04-35.76 \\
24.59-28.84 \\
30.67-29.21\end{array}$ \\
\hline $\begin{array}{l}\text { Sintered } \\
\text { alumina }\end{array}$ & Tube & 450 & 1000 & 40 & & $\begin{aligned} 0.43 & -0.57 \\
-0.07 & -0.07\end{aligned}$ \\
\hline $\begin{array}{l}\text { Sintered } \\
\text { alumina }\end{array}$ & Tube & 450 & $\begin{array}{l}243^{* !} \\
494^{* !} \\
994^{* !} \\
1994^{* !} \\
3996^{* !}\end{array}$ & $<1$ & $\begin{array}{c}-4.69--11.71 \\
-4.12--4.21 \\
-27.88--39.06 \\
1.32-1.70 \\
-6.69--10.55\end{array}$ & $\begin{array}{l}1.45-1.37 \\
1.59-1.89 \\
1.04-0.91 \\
1.61-2.67 \\
0.84-0.33\end{array}$ \\
\hline Single crystal & $\begin{array}{l}\text { disk or } 1 / 2 \\
\text { disk }\end{array}$ & 550 & $\begin{array}{l}1549 \\
3028 \\
4577\end{array}$ & $1-5$ & $\begin{array}{c}-13.08 \\
-28.69 \\
-12.31\end{array}$ & $\begin{array}{l}0.46 \\
22.14 \\
10.46\end{array}$ \\
\hline Single crystal & disk & 550 & 2000 & 40 & & 38.84 \\
\hline Single crystal & disk & 550 & 3400 & $<1$ & & 3 \\
\hline Single crystal & disk & 550 & 250 & 240 & & 28.3 \\
\hline
\end{tabular}

These weight evolutions are directly related to the amount of sodium residues and reaction products remaining on the specimen. Scanning electron microscopic (SEM) observations of the surface layer, or of crosssection obtained by fracture, clearly demonstrate the gradual formation of sub-micrometer corrosion pits (Figure 1) that cover with time all of the surface of the specimen (Figure 2). Observations demonstrate the absence of any IGC up to the interface, as the fracture surfaces remain trans-granular in all cases (Figure 1 and Figure 2). After the second cleaning, the weight variation changed its sign, from weight gain to weight loss for both sintered alumina and single crystal. The cleaning steps appeared, then, critical to ensure the correct monitoring of corrosion. It was assumed that the second water cleaning procedure (pure water - 15 minutes ultrasonic bath) was efficient enough to get representative weight variation. Additional tests were done with specimens of the $450^{\circ} \mathrm{C}-0.1 \mathrm{ppm}$ corrosion test that supported this hypothesis within roughly $10-100 \%$ of the weight loss. Indeed, some specimens presented almost no variation upon subsequent $3^{\text {rd }}$ cleaning with water and high temperature stage $\left(800^{\circ} \mathrm{C}-3 \mathrm{~h}\right)$ with $10 \%$ increase, while some others presented either a large relative increase or decrease (100\%), but limited in value as weigh variation were close to the detection limit for that specific test. These difficulties in measuring representative weight variations explained the scattering of the data, but it was assumed that the number of specimens gave mean value statistically representative of the actual weight loss. In addition, the initial stage of the corrosion to reach steady state (wetting conditions, surface finishing...), is most probably an additional source of scattering.

The morphology of corrosion for sintered and single crystal alumina appeared roughly identical as seen on Figure 2 for a weight loss within the same order of magnitude. This demonstrates that the pure and dense sintered alumina presents the same behavior as the single crystal, to the condition that the grain boundary corrosion is negligible, which is the case for this high purity grade sintered alumina. 
Courouau, J., Steil, M., Fouletier, J. et al. Single Crystal and Sintered Alumina Corrosion in Liquid Sodium. Oxid Met 87, 789-800 (2017). https://doi.org/10.1007/s11085-017-9743-3

Post print version - The final publication is available at link.springer.com

Surface before Na test

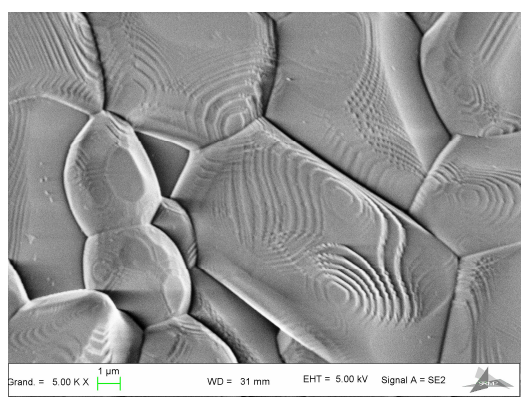

Surface after Na test

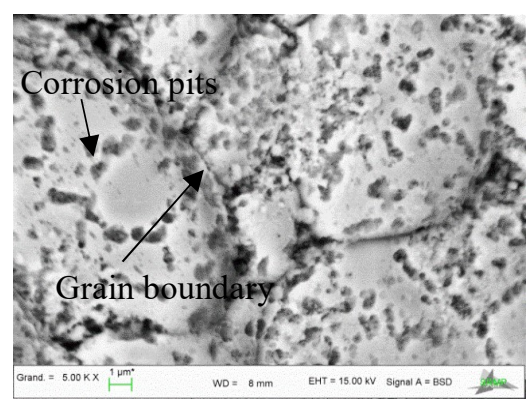

Fractured tilted specimen

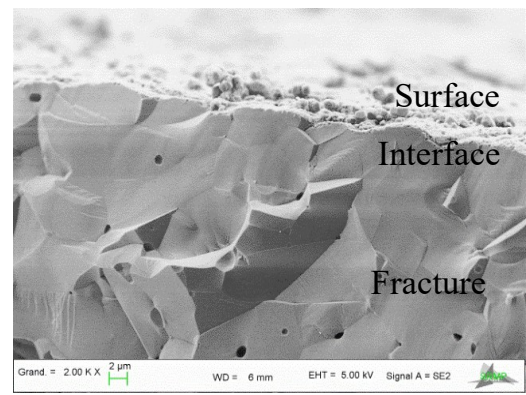

FIGURE 1. SEM observations of sintered alumina surface before (left) and after sodium corrosion (middle), and SEM observation of tilted fractured specimen (right) after sodium corrosion (1000 h at $450^{\circ} \mathrm{C}, \sim 40 \mathrm{ppm}$ oxygen).

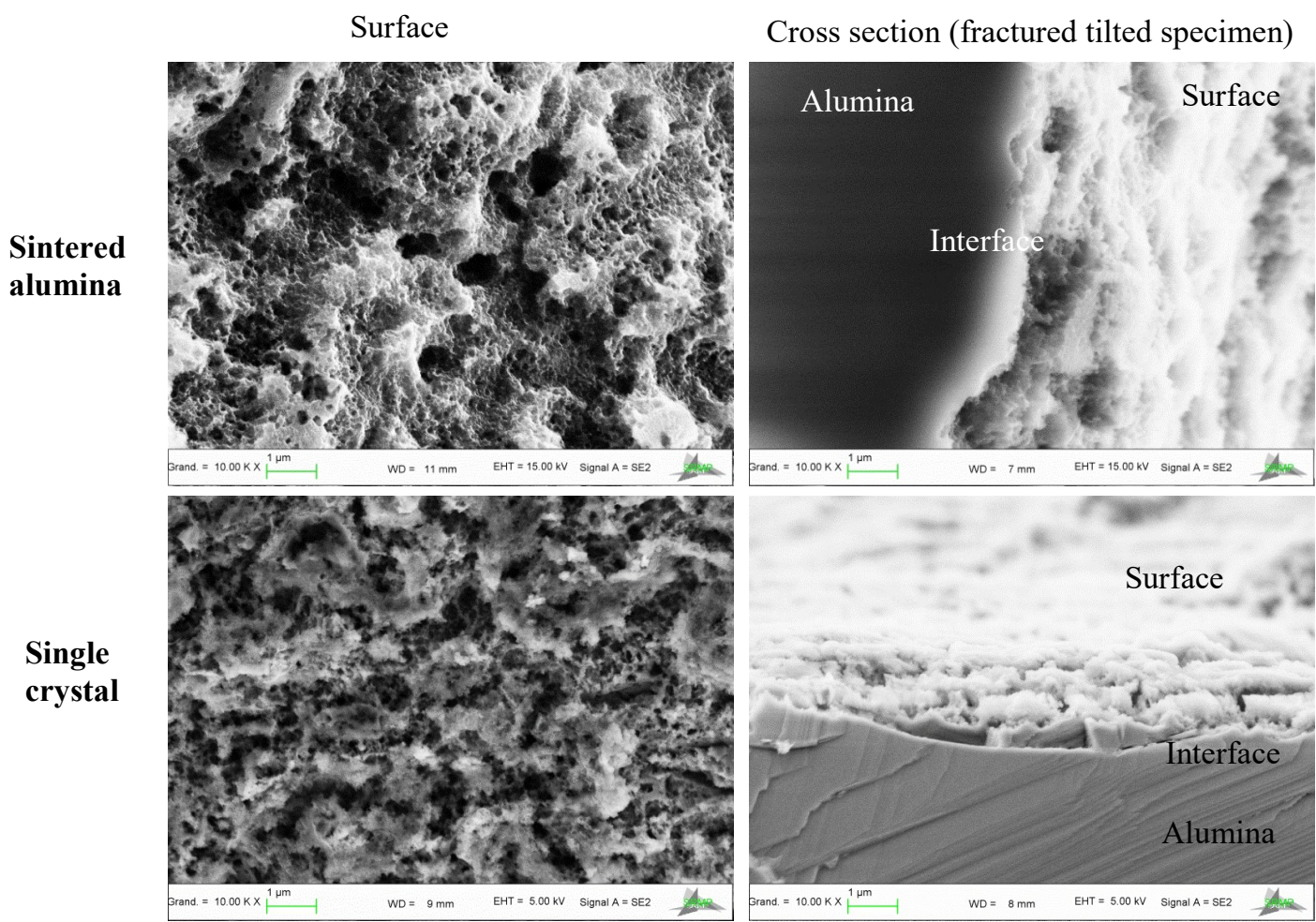

FIGURE 2. SEM observations of surface and tilted fractured cross section of the sintered alumina and single crystal after immersion in liquid sodium at $550^{\circ} \mathrm{C}, 1-5 \mathrm{ppm}$ of oxygen and $3028 \mathrm{~h}$.

The number and surface coverage of the corrosion pits tended to increase during the first few hundred hours in liquid sodium at $550^{\circ} \mathrm{C}$ and $1-5 \mathrm{ppm}$ in oxygen. Preferential formation might be promoted at grain boundaries as observed in Figure 1 on sintered alumina, but numerous pits are also formed randomly on the specimen surface. After a few thousands hours, the corrosion pits tend to cover the whole surface of the specimen (Figure 2). Steady corrosion rate is then assumed. The width of the corrosion pits ranged from a few tens to a few hundred nanometers $(50-500 \mathrm{~nm})$, offering possibility for the liquid sodium to be trapped. The order of magnitude of the equivalent residual sodium surface layer thickness after ethanol cleaning is in agreement with the observed pits dimensions as $5 \mathrm{mg} \cdot \mathrm{dm}^{-2}$ equals $\sim 500 \mathrm{~nm}$ of pure sodium, so that there is an overall good 
Courouau, J., Steil, M., Fouletier, J. et al. Single Crystal and Sintered Alumina Corrosion in Liquid Sodium. Oxid Met 87, 789-800 (2017). https://doi.org/10.1007/s11085-017-9743-3

Post print version - The final publication is available at link.springer.com

agreement in between observations and weight variation due to a more efficient sodium residue removal. At $450^{\circ} \mathrm{C}$ and $<1 \mathrm{ppm}$, the same observations are made but with a far larger exposure duration for the same effects (Figure 3). Indeed, only the first corrosion pits are observed in these conditions.

Based on these phenomenological observations, the loss of weight is interpreted as an equivalent dissolution reaction that involves the intermediate formation of sodium aluminate $\left(\mathrm{NaAlO}_{2}\right)$ with either the liquid metal or the oxygen impurities ( $\mathrm{Na}$ or $\mathrm{Na}_{2} \mathrm{O}$ ). Then, the reaction product $\mathrm{NaAlO}_{2}$ is dissolved in the liquid sodium. Indeed, a non-negligible solubility of this oxide could reasonably be assumed by comparison with other ternary oxide in liquid sodium $[15,16]$. However, the hydrolysis of $\mathrm{NaAlO}_{2}$ into soluble aluminum hydroxide $\mathrm{Al}(\mathrm{OH})_{3}$ during the sodium residue removal step is a possibility that must be further investigated. Assuming that the overall reaction rate is related to the weight loss of alumina, according to either equation 3 or 4 , the quantification of the kinetics based on weight measurement is then made possible. Weight losses of sintered alumina are plotted as function of temperature in Figure 4 at $450^{\circ} \mathrm{C}$ and $550^{\circ} \mathrm{C}$ for low oxygen concentration with the following assumptions: the standard deviation of each mean value are plotted as error bars if larger than the uncertainty of the measurement $\left(1 \mathrm{mg} \cdot \mathrm{dm}^{-2}\right)$, the weighted linear regression analysis is plotted with the $99 \%$ confidence hyperbolas only at $550^{\circ} \mathrm{C}$, and the uncertainties of the slope and the intercept are assessed as being 2 times the standard deviation of these parameters given by the weighted linear regression analyses.

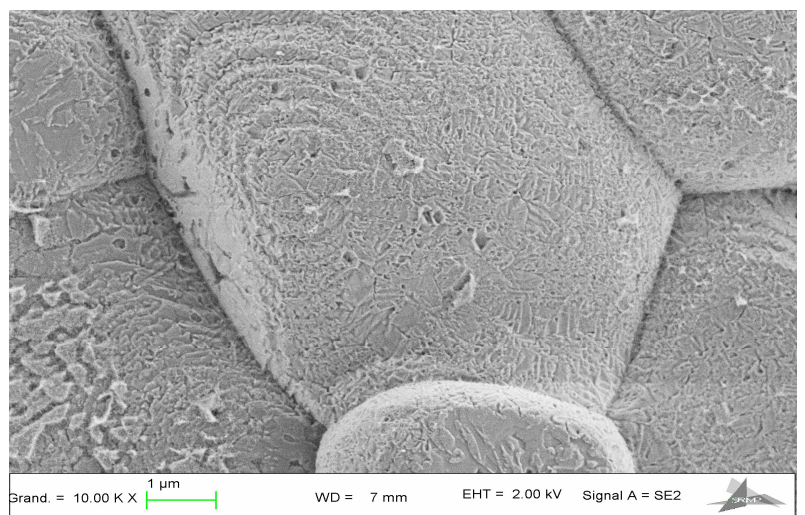

FIGURE 3. SEM surface observation of sintered alumina surface after $4000 \mathrm{~h}$ in sodium at $450{ }^{\circ} \mathrm{C}$ and low oxygen conditions.

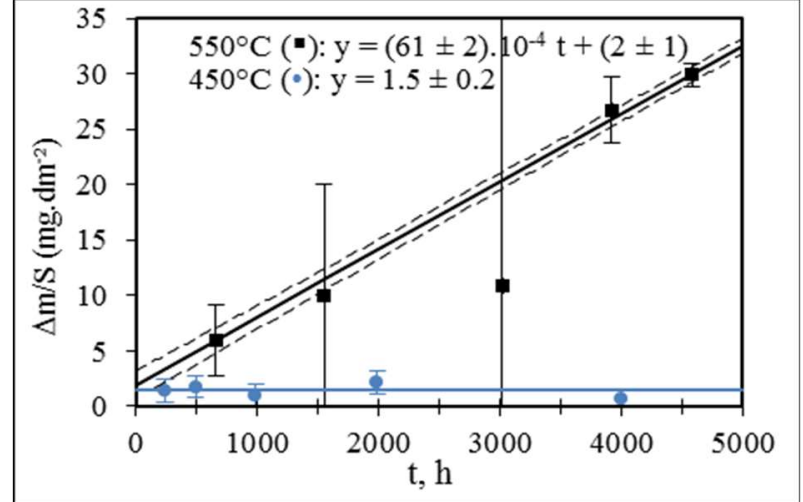

FIGURE 4. Weight loss of sintered alumina with respective weighted linear regression analyses at $450^{\circ} \mathrm{C}$ and $550^{\circ} \mathrm{C}$ at low oxygen content.

Despite the difficulty in measuring representative weight variation, the data appeared as linear with correlation coefficient close to 1 at $550^{\circ} \mathrm{C}$. The standard deviations for the weight losses appear as larger for lower durations and smaller for higher durations, which might correspond to the establishment of steady state corrosion regime, when all the surface gets uniformly covered with dissolution pits. At $550^{\circ} \mathrm{C}$ and low oxygen content, a linear kinetic is then found with good accuracy. The value of the constant corrosion rate is then assessed to $(61 \pm 2) \cdot 10^{-4} \mathrm{mg} \cdot \mathrm{dm}^{-2} \cdot \mathrm{h}^{-1}$.

At $450^{\circ} \mathrm{C}$, the weight variations are very small when compared to the uncertainty of the measurement, and close to a constant value. Consequently, within the experimental uncertainty, the corrosion rate can be considered as negligible in the conditions of the test. The intercept appears equals to $1.5 \pm 0.2 \mathrm{mg} . \mathrm{dm}^{-2}$, which is similar to the one obtained at $550^{\circ} \mathrm{C}$. If confirmed, this might be representative of the same initial corrosion phenomenon (gas desorption...).

Weight losses of single crystals at $550{ }^{\circ} \mathrm{C}$ and $1-5 \mathrm{ppm}$ in oxygen are also plotted together with the few available literature data for sintered samples and single crystal from Kano [6] in Figure 5, measured in a sodium loop: weight loss for $550^{\circ} \mathrm{C}, 1000 \mathrm{~h}$ and $1 \mathrm{ppm}$ in oxygen is $4.6 \mathrm{mg} . \mathrm{dm}^{-2}$ for a single crystal of high purity (SK), and $12.6 \mathrm{mg} . \mathrm{dm}^{-2}$ for a $99.5 \%$ purity sintered alumina (PK). First, both the sintered alumina (PK) and the single crystal (PK) weight losses are consistent with the corrosion rate obtained for the sintered alumina in similar though 
Courouau, J., Steil, M., Fouletier, J. et al. Single Crystal and Sintered Alumina Corrosion in Liquid Sodium. Oxid Met 87, 789-800 (2017). https://doi.org/10.1007/s11085-017-9743-3

Post print version - The final publication is available at link.springer.com

slightly different conditions. Secondly, the single crystal weight losses appear scattered, and noticeably lower than that of the sintered alumina, as presented in Figure 5. It should be pointed out that one point is close to the sintered alumina correlation: the $3028 \mathrm{~h}-22.14 \mathrm{mg} . \mathrm{dm}^{-2}$ point, for which the initial surface finishing was different from other samples. The 3 others specimens presenting lower weight losses had, indeed, a surface state that could be qualitatively assumed as more polished. After sodium exposure, the single crystal exposed during 3028 $\mathrm{h}\left(22.14 \mathrm{mg} . \mathrm{dm}^{-2}\right)$ presented a surface that is uniformly covered by corrosion pits (Figure 2 ). This morphology is identical to the one observed for sintered alumina (Figure 2). Conversely, the surface of the $1549 \mathrm{~h}$ single crystal specimen appeared only partially covered by corrosion pits. The observation of the surface morphologies of the specimen allows proposing that, as shown in Figure 5 with the dotted line, the corrosion rate of the polished single crystal is negligible during the first $3000 \mathrm{~h}$ of the test. After this incubation time, the weight loss increases linearly with time with a slope (बत?] $\left.63.10^{-4} \mathrm{mg} \cdot \mathrm{dm}^{-2} \cdot \mathrm{h}^{-1}\right)$ quite near the slope determined with sintered alumina samples $\left(\right.$ a $\left.=61 \pm 210^{-4} \mathrm{mg} \cdot \mathrm{dm}^{-2} \cdot \mathrm{h}^{-1}\right)$. A higher surface finishing would then induce a higher delay in the establishment of steady state corrosion. Grain boundaries of sintered alumina like the lower qualitatively polished surface finishing may promote the quicker achievement of steady state corrosion as seen in Figure 1, by offering lower energy sites for pits formation. With so little and scattered data, conclusions are not straight forward, but it seems that there is no difference as regards the corrosion rates of sintered alumina and single crystal, except in the delay to reach the steady state of the corrosion.

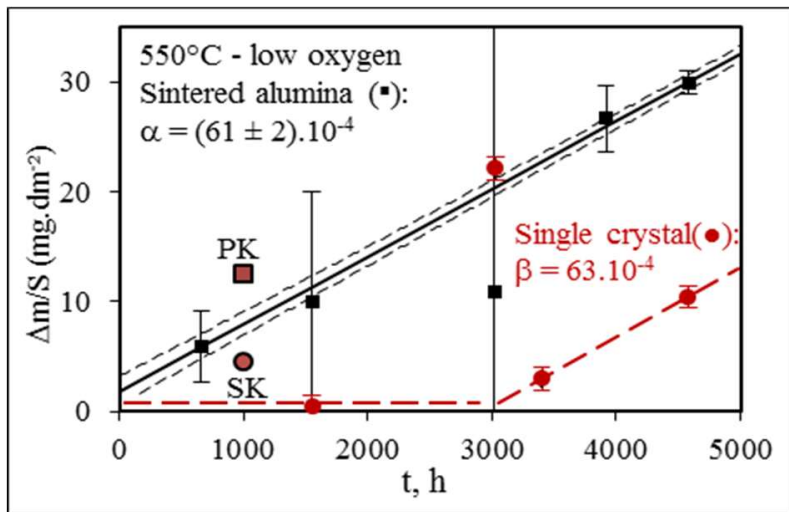

FIGURE 5. Single crystal weight loss at $550^{\circ} \mathrm{C}$ and low oxygen compared to sintered alumina and literature data (points SK and PK).

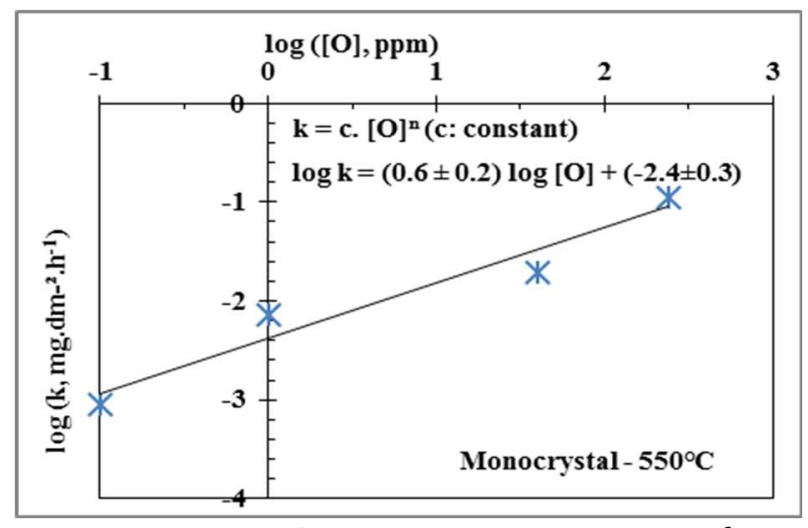

FIGURE 6. Corrosion rates vs. oxygen content for single crystal at $550^{\circ} \mathrm{C}$ for the determination of the order of reaction (errors set as twice the standard deviation).

The linear constant of the weight loss rate $(\mathrm{k})$ was plotted as a function of the oxygen content in the bath, at $550^{\circ} \mathrm{C}$ in Figure 6 . Assuming that the linear constant obeys the relationship: $\mathrm{k}=\mathrm{c}$.[O] $]^{\mathrm{n}}$, in which $\mathrm{c}$ is a constant, the order of the reaction, $n$, can be estimated by plotting log $\mathrm{k} v \mathrm{vs}$. log [O]: the order of reaction corresponds to the slope and was found equal to $0.6 \pm 0.2$. This straight dependence with oxygen content supports the conclusion that reaction (3) is the main chemical reaction involved in the corrosion mechanism, as this reaction (3) leads to a 0.5 order of reaction with respect to oxygen content at the temperature of $550^{\circ} \mathrm{C}$.

\section{CONCLUSION}

For sintered alumina with no open porosity and high chemical purity especially as regards silica, no intergranular corrosion was observed during the tests achieved in static liquid sodium at $450^{\circ} \mathrm{C}$ and $550^{\circ} \mathrm{C}$ with various oxygen content and for duration up to 4600 hours. No clear difference in the behavior of single crystal alumina with sintered alumina was also determined. Corrosion appears to proceed by reaction of $\mathrm{Al}_{2} \mathrm{O}_{3}$ with dissolved oxygen $\left(\mathrm{Na}_{2} \mathrm{O}\right)$ to form sodium aluminate $\left(\mathrm{NaAlO}_{2}\right)$, which is dissolved in the liquid sodium upon a 
Courouau, J., Steil, M., Fouletier, J. et al. Single Crystal and Sintered Alumina Corrosion in Liquid Sodium. Oxid Met 87, 789-800 (2017). https://doi.org/10.1007/s11085-017-9743-3

Post print version - The final publication is available at link.springer.com

mechanism still to be elucidated. The corrosion morphology is equivalent to a dissolution mechanism. From weight loss measurement, linear kinetics is found with a constant dissolution rate of $(61 \pm 2) \cdot 10^{-4} \mathrm{mg} \cdot \mathrm{dm}^{-2} \cdot \mathrm{h}^{-1}$ at $550^{\circ} \mathrm{C}$ and low oxygen content $(1 \mathrm{ppm})$. At $450^{\circ} \mathrm{C}$ and low oxygen content, the corrosion rate is negligible with the test conditions achieved. An order of reaction with respect to dissolved oxygen content of $0.6 \pm 0.2$ is found. No such data were yet available to our knowledge in the literature.

Given these results, and to the restriction of the hypotheses taken, for normal operating conditions where the oxygen content is assumed to be buffered to a low but unknown value by the structural steels thanks to the formation of sodium chromite [13,14], the corrosion rate of alumina can be expected to be very low $(0.01 \mu \mathrm{m} / \mathrm{y}$ at $400{ }^{\circ} \mathrm{C}$ ), but the data should be more accurately determined, especially in the low temperature and oxygen domains. As a conclusion, this study is a first step to the better understanding of the mechanisms of degradation, which is a guide for the fabrication of specific ceramics that would be compatible with the liquid metal, as well as a guide for the accurate predictions of very long service life-time of such material in reactor conditions.

\section{ACKNOWLEDGMENTS}

The CEA SFR R\&D projects on Severe Accidents, Core Materials and Na Technology are gratefully acknowledged for funding this research, as well as B. Duprey from the same laboratory and V. Ghetta from the CNRS-LPSC for their help and support in obtaining the data.

\section{REFERENCES}

1. Dautray R., Bréchet Y., Friedel J., in Les fluides caloporteurs pour neutrons rapides, Académie des sciences, EDPscience (Les Ulis), 2014.

2. Courouau, J-L., Balbaud-Célérier, F., Lorentz, V., Dufrenoy, T., International Congress on Advances in Nuclear Power Plants (ICAPP '11), ANS, paper 11152, Nice, France, May 2-5, 2011.

3. Taylor, R. G., Thompson, R., Journal of Nuclear Materials (1983) 115(1): p. 25.

4. Fouletier, J., Steil, C., Courouau, J-L., Ghetta, V., in Ateliers bilan des actions soutenues 2009 GEDEPEON, Paris, France, 18-19 Novembre 2009 (gedeon.prd.fr ).

5. Macia, F., Steil, C., Fouletier, J., Ghetta, V., Muccioli, A., Lorentz, V., Courouau, J-L., in Matériaux 2014, Montpellier, France, Nov. 24-28, 2014.

6. Kano, S., Yoshida, E., Hirakawa, Y., Tachi, Y., Haneda, H., Mitsuhashi, T., in Liquid Metal Systems, Editor Borgstedt H. U. and G. Frees, Plenum Press, New-York, 1995: p. 85.

7. Mayer, H., Resistance of oxide ceramic products to corrosive liquids. 2010 (friatec.de ).

8. Outoupouku HsC sofware v5.0.

9. Jung, J., Reck, A., and Ziegler, R., Journal of Nuclear Materials (1983) 119(2-3): p. 339.

10. Barsoum, M., Journal of Materials Science (1990) 25: p. 4393.

11. Courouau, J-L., Lorentz, V., Tabarant, M., Bosonnet, S., Balbaud-Célérier, F., in: International Conference on Fast Reactors and Related Fuel Cycles: Safe Technologies and Sustainable Scenarios (FR13), Paris, France 4-7 March, 2013.

12. Courouau, J.L., Rivollier, M., Lorentz, V., Tabarant, M ., in: International Congress on Advances in Nuclear Power Plants (ICAPP-15), (paper n¹5417) Nice, France, May 3-6, 2015.

13. Rouillard, F. Courouau, J-L., Duprey, B., Mathieu, S., Vilasi, M., Bouizi, Y, Boisonnet, G ; Pedraza, F., Proriol-Serre, I., in: HTPCM, Les Embiez, France, 15-20 May, 2016. (Oxidation of metals, in press).

14. Courouau, J.L., Rivollier, M., Lorentz, V., Tabarant, M ., in: EUROCORR 2015 (paper n860), Graz, Austria, September 6-10, 2015.

15. Weeks J. R. and Isaacs H. S. in: Chemical aspects of corrosion and mass transfer in liquid sodium, NewYork, USA, October 19--20, 1971.

16. Rivollier, M., Courouau, J.L., Giorgi, M-L., Jomard, F., in EUROCORR 2015 (paper n733), Graz, Austria, September 6-10, 2015. 